\title{
Treatment of Love in Khushwant Singh's I Shall Not Hear the Nightngale
}

\author{
Namita Panda \\ Asst. Professor, Dept. of English, KIIT University, Bhubaneswar, Orissa, India
}

\begin{abstract}
Much scholarly work has been done on Khushwant Singh but it is fair to say, little work has been done on his treatment of love in his novels. The present paper seeks to provide a modest study of the novels of Khushwant Singh, the most popular Indian writer in English. It attempts to make comprehensive critical comments on his fiction I Shall Not Hear The Nightingale with an emphasis on his treatment of love in the above said novel. His second novel I shall not hear the Nightingale basically deals with the maternal love. It is Sabhrai, whose matriarchal strength sustains the family in its time of crisis. On one side, where the novel is replete with sexual, amorous activities, practiced by different characters, Khushwant on the other side portrays a pious, religious character, which is without a stain. She is a source of inspiration not only for her husband but also for her son and daughter. It is through Sabhrai's Character, we come across another illusive kind of love i.e. divine love. A religious woman like Sabharai believes that this love is the greatest of all. While for Champak, Beena, Shunno love is skin communicated thing.
\end{abstract}

Key words: divine love, I Shall Not Hear the Nightingale, Khushwant Singh, Maternal love, Treatment of Love

I shall not hear the Nightingale centres on a middle class Sikh extended family in the days before India's independence. The story is set at the backdrop of 1942. The novel reveals events very realistically. Although the novel deals with the political situations, it cannot, however, be termed as a political novel. It is because he does not make any significant reference to an elaboration of the Quit India movement. More over, none of the characters is seen to be involved in political philosophy seriously. But it gives us a peep into the life and atmosphere during that period. It does give some details about the countrymen's longing for freedom and attempts by some enthusiastic young men preparing for terrorist activities to free the nation from foreign oppression. J.W.Bryant aptly says, "This short novel by a cosmopolitan Indian scholar presents a drama of family loyalties which can be enjoyed by the Western reader with little or no knowledge of Eastern affairs............." (qtd. in Singh P.K. p.57) ${ }^{1}$

The opening scene is highly significant and carries a symbolic meaning. Sher Singh and Madan, like many other misguided young men wanted to bring India's freedom through violence. They participate in a target practice as they all want to be terrorists and are with firm resolution to kill as many English men as they like.

So, in order to baptize their weapons Sher Singh shoots a crane. Its mate followed and tried to attack them because 'If one of a pair is killed, the other dies of grief' (Singh P-06) .The Sarus crane has been presented here as a symbol of the motif of love, mating and sacrifice. On the contrary the cry of the crane symbolizes the present era of violence and venom and bloodshed. This symbolic representation is well expressed in the following lines:

The anguished cry of the flying crane was almost human. If he did not silence it, it would continue to haunt him for a long time. If both of the pair were dead; perhaps they would be together wherever cranes went after death. Sher Singh took out the magazine of his rifle and pressed six bullets in it. He followed the crane's flight with his barrel and fired when the bird was almost above him. The bullets went through one of the wings. The bird wavered badly in its flight and some feathers came floating down. (Singh p.6)

Love in its pure form can be seen among the animals also. It is really heart warming to see crane's love for its dead mate in the following lines -

Before they got clear of the Swamp the other crane flew back and started circling over them. They saw it high above in the deep blue sky catch the light of the setting sun then heard its cries piercing the stillness of the dusk. Sher Singh ignored requests to have another go at the flying bird, in any case it was too high and the light was failing fast. When got to the canal bank, it became dark. The cranes flew lower and lower till they could see its grey form with its long legs almost above their heads. They shoo'd it off. The bird disappeared in the dark only to come back again and again". Its crying told them it was there all the time, trying to reclaim its dead mate. (Singh 7)

Khushwant Singh, by presenting the scene of Sarus' killing, has indirectly pointed out that neither Sher Singh nor Madan Lal understood as to what love is and what man's feelings for woman are. Due to Sher Singh's 
over ambitions, he ignores the sexual urge of his wife, Champak while Madan Lal behaves like a sex maniac who indulges himself simultaneously with many women.

On their way, the village headman stopped him and asked him to show his license. Sher Singh showed his father's shotgun license from his pocket. When Sher Singh was introduced as senior most magistrates Sardar Buta Singh's son, the headman withdrew his demand and on the contrary started flattering him. Thus situation is ironical satire on the duplicity of character of Lambardar and inequality on the application of law by them, treating powerful persons above the law. Lambardar as suspected by Sher Singh and his friends was a paid police informer. It is his crave from money, his love for power, that eventually in the course of time; he was killed by the misguided Sher Singh.

In their excitement, Madan Lal, friend of Sher Singh introduced his friends with false names. Sher Singh also forgot to pick up six empty cases of bullets at the place of target practice. There opening scene indicates the progress of situation and character of Sher Singh.

As Sher Singh and his friends discovered that the village headman was a paid police informer. The headman was the one, who had been informing every activity of Sher Singh to the Deputy Commissioner. More over, this village headman tried to blackmail and extract money from Sher Singh as well as his friends. So, one particular evening, Sher Singh along with his friends killed the village head master. The Deputy Commissioner suspected the hand of Sher Singh in the murder of Jhimma Singh, the village head master.

As a modern novelist, being influenced by Western civilizations, Khushwant Singh has employed unusual sexual culture in the novel through champak. Champak is a sex hungry woman. She is a unique lady in the whole range of Indian fiction in English. We find a glimpse of Champak through Sher Singh in the following lines:-

He woke with a cry of terror and looked round for his wife. His cry had not wakened her. She lay like a nude model posing for an artist. On hand between her thigh covering her nakedness and the other stretched away to expose her bust. (Singh p.18)

Champak is an unusual lady, who always indulges herself in sexual activities. Champak, the name of a beautiful flower is very much appropriate for her. She also openly exhibits her beauty. Even on Baishakhi Day, the New Year Day, while her mother-in-law Sabhrai was seen going out or engaged in religious activities, Champak was seen indulged in highly sensuous and sensual activities. She took off her entire clothing and stood in front of her mirror of her dressing table to admire the contours of her chocolate body. Khushwant Singh very rightly puts the scene as below.

She loosened her hair and turned round to see how she looked from behind. Her hair fell to the point at which her buttocks rose like softly rounded water melons. There are dimples on either side of rear waist. She turned round once more, inhaled deeply and lifted her breast with the palms of her hand and then ran her figures round her nipples till they became round like berries. She clasped her arms above her hand and wriggled her hips is he manner of hula-hula dancers. She drew her belly in as much as she could and stroked it with her hand down on either side to her knees. She studied her face and figure in all the postures she had seen in all the postures she had seen in photograph of nude models. She found the reflection in the mirror to her satisfaction. (Singh pp.49-50)

The novelist sketches Champak as a sex-maniac who in her exhibitionism does not spare her minor teen-aged servant Mundoo who saw:

Champak hid her nakedness with her hands between her knees. Her raven black hair fell on either side of her neck. Her breasts looked out from between her arms. Mundoo stared stupidly at her without replying and then started to back out of the door. (Singh p.51) Sher Singh loves his wife but it seems as if he doesn't understand his wife. He doesn't care for her personal feelings, hobbies and likings. His conversation with his wife contains frequent references to his political routines. He takes it for granted that Champak loves this. These lines describe this. I must tell you what happened today. My God! I nearly died of shame .........the embarrassment had nearly killed me. (Singh p.51) ${ }^{7}$ But Sher Singh paid little attention to these and started recalling what had happened that day. He Says,

What a turn out at my meeting. I firs we had a march past of the student volunteer corps. No one had seen such smartness from civilians before. The S.V.C. has come to mean something. Then, I addressed the meeting. There was absolute pin-drop silence. (Singh p.52)

Sher Singh is no match for her in sex. He is the picture of an incomplete man, who fails to act physically to satisfy the sex urge of his wife and is also unable to act on his own political ideals of nationalism.

Ironically the writer has given his name as Sher Singh, but in reality he acts just opposite to the meaning of his name. As depicted in the beginning of the novel, on one hand he wishes to kill as many English men as possible, but even the killing of a Saru disturbs his peace of mind. Through this opening scene Khushwant Singh introduces Sher Singh, the son of Buta Singh, a senior Magistrate in the British Raj as a young man initially caught in a conflict between nonviolence and violence, between a comfortable life provided 
by his father in the British Raj and his own individual pressure to form a group of terrorists working against the British Raj.

Sher Singh has prematurely married Champak and Champak is hyperactive in sex. Sher Singh's inadequacy, in satisfying her wife in sex is aptly presented in the following lines:

Champak had taken off her Kimono and lay stark naked on her belly she had the pillow between her arms, her legs were stretched apart. Sher Singh knew what this meant 'My God I feel flagged out, he said wearily and switched off the light (Singh p.48)

So, though they live together physically, they do not come together psychologically and spiritually. Champak is not satisfied in her conjugal relationship with Sher Singh. She tries to draw attention of Sher Singh towards sex, while Sher Singh keeps on talking about his political meetings or war. There are numerous comical instances of Sher Singh trying in vain to avoid his amorous wife. Champak at times pretends to be in the throbs of a nightmare and so maneuver herself into Shrer Singh's arms. At other times, she brings up the subject of either Mundoo coming on to him while she was bathing in the nude, or Madan staring at her breasts or some other man gazing at her. Khushwant Singh believes that this incompatibility leads to infidelity. She pretends to be very loyal to Sher Singh but behind him she passionately loves Madan.

Khushwant is a keen observant. A frank discussion about sex is not a taboo to him. It is his openness which is liked by his readers. Santha Rama Rao says, "Khushwant is direct to the point of brutality, unsentimentally observant", and in his bold characterization he is ready to explore the least appealing aspects of human nature and relationships" (qtd.in Singh P.K p.57)

Writer P.K.Singh says:

By exposing the unfulfilled sexual desires of Champak, he wants to draw people's attention towards certain drawbacks of Indian Joint family, where married couple cannot meet openly to appease their carnal desire. (Singh P.K p. 66)

Khushwant Singh Ironically says that though India is the land of the Kama Sutra and phallus worship, sex is practiced in conditions which provide neither the time nor the opportunity for a man to arouse the passion of his women which makes her yearn for lusty fulfillment. He believes that India, the land of Kama Sutra, is really unfortunate to have such as unpleasant and unfavorable socio-Sexual situation for young married couples. According to him, it is highly ironical that Kama Sutra, a historical book on eroticism (sexual activities), are adopted and being translated by Greek and people of other countries to learn methods of getting carnal pleasures prescribed in it. But in India, married couple hardly gets opportunity and privacy to practice its devices.

This unfulfilled of sexual desire leads many of them to lean towards other alternatives. Khushwant candidly depicts such man-woman relationship in this piece of work. He clearly portrays the picture of a trapped married woman, who when gets opportunity easily indulges herself in extra marital relation through the character of Champak. Like D.H.Lawrence, Khushwant Singh also believes that suppression of sex has always negative consequences. He writes:

Unfulfilled sexual impulses result in an obsession with sex and in many perversions which result from frustration, sadism, masochism and most common of all exhibitionism. (Singh p.48)

By her manipulative skill, Champak manages to enjoy sex by being involved in a flirtation with Madan in Shimla. Champak's husband Sher Singh has no time to satisfy her physical needs and hence she gets sexual fulfillment from Madan whenever she finds privacy. She is more frank and open with him than with her husband who is not much interested in such things because of his mission of a revolutionary. Like Lawrence Khushwant Singh thinks there is no relation between sexual fulfillment and morality or fidelity. In this context, comparing Champak with D.H.Lawrence's Lady Chatterley, Ranjan Kumar says:

In Lawrence's Lady Chatterley's Lover the wife is very much loyal to her handicapped husband but for the fulfillment of her sexual urge she goes to another person. (Kumar Ranjan 60)

The following erotic lines, sensuous, passionate and vulgar loving scenes of Madan and Champak rightly support the above said point.

He undid the top buttons of her shirt and let his hand slip on to her warm, rounded breast. She turned her face up to him, their mouths met with hungry passion. Madan gently pushed her against the wall on the side and kissed her on her eyes and glued his lips on hers. The breath in his nostrils became heavy. (Singh p.127)

As a writer, Khushwant Singh is gifted with extra-ordinary ability to discuss very sensitive aspects of human relationship is really very wonderful. He believes in frank narration of incidents and situation with a touch of open heartedness. In this context, Khushwant portrays beautifully another character, Beena, who is the daughter of Buta Singh. She is found to be studying in a college. She seems to be in her adolescence - She was also seen to be tempted for a while by Madan. The circumstance of her studying together with Seeta, Sister of Madan Lal, led her to visit the movie theatre in the company of Madan, who was a cricket star of the college and who possess a good figure. So it did not take much to seduce Beena. It can be clearly observed in the following lines. 
As soon as the lights went out, Madan put his hand in the arm of Beena's Chairs. This time she knew that it was not an accident. She could hardly believe that anyone, let alone Madan, wants to make a passionate plain and simple girl like her. It was unbelievably flattering. But he was married and it was obviously wrong. Beena had no doubt about Madan's intentions as his fingers closed round her elbow.........Madan began to caress her arm .Beena did not move. Then his hand brushed against her breast .she shrank away into the farther corner of her chair. (Singh p.41)

Khushwant Singh believes that girls at sixteen are easy to seduce. Through the character of Beena, the novelist wants to give a warning to the adolescent youth not to indulge themselves in sex affair. It is again through the character of Beena, he wants to show that premature love leads to agony and suffering.

Beena was accompanied by Champak to go to Shimla, where Madan and his sister Seeta had also turned up. On a particular day when Madan and Beena had decided to meet at night, Beena even though she knew that what she is going to do is socially not accepted, but she should not resist her temptation. She decided to go to Madan's room. As she switched on the light she could see the letter sent by her mother. Khushwant Singh very cleverly warns the entire adolescent youth to be very careful, who don't know the difference between right and wrong.

The following passage, which is a part of Sabhrai's letter, clearly depicts the novelist's intention.

O, Black back, why lovest thou.

The pleasure of fenced-in fields?

Forbidden fruit is sweet but for a few days,

It entices and ensnares.

Then leaves one sorrowing . (Singh 129)

Khushwant Singh believes that sex is a physical manifestation of God and it is a not a sin. But when sex is practiced by a prematured person who hardly understands the difference between love and lust, the consequence can be very dangerous. This is one of the ideas explicit in the novel, which bears social significance.

Knowing that sexual involvement with a married man like Madan will never be accepted, still the desire to go into Madan's room brought a feverish longing in her body. She was found to be on the horns of a dilemma. This can rightly be observed in the following lines.

The desire to go into Madan's room brought a feverish longing in her body. It was followed by visions of Madan's wife and child and the hot perspirations turned cold and froze on her, Then came the figure of Madan, in his cream coloured, hand knitted sports sweater and flannel trousers - tall, handsome overpowering stripping her and taking her as a man should take a woman. Once more the implications of what would follow her mother's cold censorious eyes, the words in the letter burning through the thickness of the pillow........... "Forbidden fruit is sweet but for a few days. It entices and ensnares, then leaves one sorrowing" . The image followed each other in quick succession, alternatively rousing hot passion and immersing her in cold water. (Singh p.130)

But eventually her mind became possessed by the memory of Madan and decided to go to Madan's room. But to her utter surprise, she found Madan's door to be shut. It was bolted from inside. She stood rooted to the ground like a statue as she came to know that Madan, whom she thought to be her lover, was sexually involved with Champak. The novelist has portrayed its effect on Beena thus: "She stood rooted to the ground like a statue. All longing turned to cold, sickening hate". (Singh p.116)

Beena, couldn't take the psychological stress easily and fell sick, When Sabhrai came to meet her daughter. Beena clutched her mother by the waist and burst into tears. Khushwant Singh aptly describes the suffering of young girl, Beena in a very realistic manner in these lines - "The girl cried, sobbed, sighed and then fill silent". (Singh 145)

A strangely written character is of Madan Lal, Sher Singh's friend and comrade against the British. Madan Lal is the cricket star who has both Champak and Sher Singh's Sister Beena lusting for him. Khushwant, by portraying the character of Madan, wants to give a message to the society that of all human emotions, the most basic, beautiful and controversial one is love. Our entire lives are dominated by this and everything else is measured by love. Sexuality is first and foremost way that God chooses for us to be here on earth, to enjoy this energy of love in the physical place. But unfortunately people, like Madan forgets this very concept of love.

Through the character of Madan, Khushwant portrays the wickedness and wrongs of man. The Sexmaniac counter part of Champak is Madan, who enjoys sex simultaneously with Beena and Champak. Madan and Sher Singh's families maintain cordial relationships. This very fact gives Madan Lal easy accessibility to Sher Singh's wife Champak and his sister Beena. While they all were in Shimla, Madan could easily convince Beena to come to his room at night and at the same time he managed to call Champak, who was already enamoured of him for his manly qualities and handsome personality to his room. But Madan became a victim of his own plans. He had invited Beena and when his arrangement with Champak finalized he could not tell Beena not to come, apologizing to her for making an illegitimate proposal in a very weak emotional state. 
Other characters which draw our attention are the characters of Shunno and Peer Sahib. Shunno is a middle aged widow, who happens to be a domestic servant in Buta Singh's household. As she has been serving Buta Singh's household since a long time and she could run the house single handed, she has the habit of bullying her fellow servant like her personal slaves. Mundoo, a thirteen year old servant was also annoyed with Shunno for her bossing over. So, to give her a piece of mind, he decided to add red ink into her drinking water vessel. So, Shunno was very much scared seeing the red stain in her finger when she was rinsing her hands. She decided to visit peer sahib, a Muslim saint to cure her mysterious ailment.

Peer sahib, a Muslim saint was young man at thirty, was a shrewd tall and wiry young man. He had a strong and mellifluous voice. He has inherited the tomb of Hazrat Sahib. He spends most of his time in praying and giving spiritual guidance to the people who flocked to the tomb. He is a person whose conception of celibacy is very light.

Through the characters of Peer Sahib and Shunno the novelist has shown the intensity of sex-hunger being as powerful as it knows no bounds and breaks to pieces the restraints of all social, moral, ethical and religious virtues and even the fear of God does not dissuade either the Hindu window or the Muslim Peer Sahib from sex.

On one particular day when Shunno approached him to get rid of the strange disease, he attempts to seduce her by calling "daughter" and slowly, step by step he was found to be enjoying sensual pleasure with her.Khushwant Singh's art of characterization is very much realistic. He has dealt very nicely with the complexities of human behaviour. Here readers are surprised to see how Peer Sahib, a pious person in selfdefense rationalizes his discreditable act by making himself believe that he is not violating the rules of celibacy by indulging himself sexually with Shunno because she might be brought on the right path by doing so. He has vividly described the discreditable act in the following lines:-

Here was a man twenty year younger, strong and virile with an untamed last savagely tearing off the padding of respectability with which she had covered herself. He stirred up the fires of a volcano which had all but become extinct. It was all wrong, but it was deliciously irresistible. It was like an itch which begs to be scratched till it draws blood.

The two lay on the hard brick floor of the starlit court yard till the early hours of mornings................ Not a word of affection or explanation passed between them. (Singh p159)

Khushwant Singh is one of the most powerful contemporary Indian novelists in English. He is more concerned with thoughts, emotions and sensation than with action, experiences and achievement. Khushwant Singh's portrayal of men women relationship has been influenced and conditioned by the existing intricate social situation. Man-woman relationship seems of particular interest to him in most of his novels. In this context Mr. P.K. Singh aptly says,

The illicit sexual encounter with peer Sahib and Shunno run counter with the illicit affairs of Champak and Madan. Madan and Champak belong to the upper stratum of Indian hierarchical society and Shunno and Peer Sahib are from lower section of society. But their repressed carnal desires are universal and same. Their tendencies of'tearing off the padding of respectability"are the similar. (Singh P.K p.70)

Lust is incredibly strong feeling that can prove to be almost uncontrollable. Man-woman whether they wear rich clothes or tattered clothes, their inner urge for sex are almost same. Lust is incredibly strong feeling that can prove to be almost uncontrollable. Khushwant Singh attempts to depict and expose the "tearing off the padding of respectability" must not be termed as pornographic as they encompass a realistic picture of society. Santha Rama Rao says,

Khushwant is direct to the point of brutality, unsentimental observant, and in his bold characterization he is ready to explore the least appealing aspects of human nature and relationships. His humour expertly integrated with an essentially sad and cynical story - is wild, broad, unsparing. (Singh P.K p.57)

Rosanne Archer commenting on the novel says:

It is sometimes interesting in spite of one dimensional characters heavy handed plotting, a flattened climax and dollops of sex pile on irrelevantly.......( Dubey p.97)

Here another thing is worth noticing, there are so many bonds formed in life that show great love and guidance. One such bond can be seen in I shall not hear the Nightingale in the light of father-son relationship. The father-son relationship in I shall not hear the Nightingale is little awkward because the ideologies of son and father are way apart. They do not understand each other. There is a communication gap between them and all the communication is carried through Sabhrai.

Buta Singh's ancestors had served the British and his own son was on the side of the revolutionaries. Similarly Sher Singh was also sailing in two boats. Sher Singh is a queer combination of youthful recklessness and self-interest. He thought that he would take the undue advantage of his father's official position and would also become the heroic leader of a band of terrorists. But unfortunately he could not make it as he could not put his legs in two boats. This is clear from the following lines which is full of self realization.

He had somehow believed that he would not muddle through, getting the better of the two worlds: the one of security provided to his father who was a senior magistrate and the other full of applause that would 
come to him as the heroic leader of a band of terrorists. Now for the first time he realized how utterly incompatible the two were and he simply had to make a choice. (Singh p.14)

But in reality he could never make a choice between two worlds. The conflict in Sher Singh's mind is between his dream to be the leader of the terrorist group and his love, attachment and respect for his father.

From many instances it is proved that Sher Singh knows that his father who is trusted by Mr.Taylor, the Deputy Commissioner, will be defamed and there would be a crack in his loyalty and integrity. Sher Singh's concern for his father is reflected in the following lines:

Mr. Taylor had been particularly good to his father whom he trusted more than any other officer in the district, that trust would be lost forever. His father's career in service and hopes of recognition for what he was doing for the war would be dashed. (Singh p.14)

Similarly Buta Singh has a split personality and practically like his son, he was sailing in two boats.

The clash in Buta Singh's mind is between his loyalty to the British Raj and his love and care for his son. Though father's and son's ideologies were wide apart yet they care for each other's well being. Buta Singh, like any other parents also keeps on telling his son the right and wrong paths of life .on one occasion Buta Singh advises his son as follows

Don't say anything which may cause trouble. Remember my position. I do not mind your hobnobbing with these nationalists......as a matter of fact, it is good to keep in with both sides-but one ought to be cautious (Singh p.25)

Sher Singh also in spite of their difference of their ideologies; display a lot of love for his father.

When Sher Singh was released from the jail, he was brought back to home by his friends and followers. Initially Buta Singh could not make any guesses for his son's release. But when he found his son with garlands around his neck, his joys knew no bound. He forgot all the differences of opinion which had poisoned their relationship over the past months. All the spitefulness submerged in the applause of triumph.

Following lines are replete with filial tenderness and affections of Buta Singh for his son She Singh.

A dozen young men rushed forward to congratulate the magistrate. It was then he noticed his son loaded with garlands. Father and son fell into each other's arms, all differences of opinion; all ran court which had poisoned their relationship over the part months were submerged in the applause of triumph". (Singh 252)

Further critical analysis of Buta Singh's character gives a glimpse of his love for power. It is through the character of Buta Singh the novelist gave a chance to his readers to mock at the obsequiousness of the servile Indian Civil servants of that time, who were at British officers' beck and call.

He has been portrayed as such a character who thinks that his life and job depend on the whims of his British masters is apt to be cringing and fawning. He is often excessively, sickeningly and insincerely polite. It is not that John Taylor Buta Singh's officer is altogether unaware of Buta Singh's intentions as he once said to his wife: "Poor Buta Singh is split between the past and the future; that is why he appears so muddled in the present. He is not as much of a humbug as he appears to be. (Singh p.218)

There are many such instances where it can be observed how he bows to his British master and attend on their slightest wish. One such incident is described below.

Buta Singh you mustn't misunderstand my temper. I am sorry if I sounded impolite. I did not mean to.”

Buta Singh's face lit up with a broad smile. "Sir, I have to work with you every day. If I start misunderstanding your anger-which I must say is very rare-our work would stop. I have always said, and will say again that it is a subordinate's duty to understand his officer's moods as well as his method of work. When you tick me off, I consider it a privilege because then I know I have made a mistake and (Singh p.73)

The characters in the novels are realistic and life like. The central character in the novel is of Sabhrai, the wife of Buta Singh. She has three dimensional characters. She is "Saviour of lost souls", having the instinctive understanding of life. She becomes the central character of the novel by virtue of her moral values and instinctive wisdom. Sabhrai is the epitome of love, goodness. She becomes the central character of the novel by Virtue of her moral values and instinctive wisdom.. Sabhrai, the devoted wife of Buta Singh is presented in the novel as a replica of common Indian housewives, who are generally devoted to the services of family members and also religious activities. She is a pious, religious lady, for whom Granth Sahib was the source of all knowledge and inspiration. She, like all mothers blindly loves her son and daughter.

On one side, where the novel is replete with sexual amorous activities, practiced by different characters. Khushwant on the other side portrays a pious, religious character, which is without a stain. She is a source of inspiration not only for her husband but also for her son and daughter.

It is through Sabhrai's Character, we come across another illusive kind of love i.e. divine love. A religious woman like Sabharai believes that this love is the greatest love of all. She is essentially a spiritualist; so often she quotes lines from Guru Granth Sahib which shows her unflinching faith on Guru. She finds her own comfort in her worship of her Guru and reading of Guru Granth, the holy book every day.

On one side readers denounce love as that is lust. On other side readers appreciate it when it comes in the form of maternal love in its tender form. While for Champak, Beena, Shunno, love becomes skin 
communicated thing, for Sabhrai, it is very much celestial. When her son was in jail she went to the extent of spending a chilly night in Gurudwara in order to save her son's life. She did not hesitate to even sacrifice her life for the release of her son. She sacrifices her life for her son, displaying a true mother's instinct by spending an entire cold night in Gurudwara praying and praying. Her unflinching faith on God and his sacrifice gets a clear picture in the following lines.

Not many people stay in temple after the evening service is over......Only those stricken with sorrow spend the midnight hours in different corners crying and praying for peace......Sabhrai washed her hands and feet in the cistern and went down the marble stairs gripping the silver railing on the side............ she sat down on the hard marble floor. An icy wind blew over the water, through the trellised fence, into her bones..........Sabhrai did not know what prayer one recited during the night; so she went through all she knew by heart. When she had finished the clock had struck two. But the tumult in her mind was not stilled. They were going to hang her son if he did not mention the names of the other conspirators..... She felt he son's presence between her arms and more tears flooded down.........so the tumult continued and the tears continued and the tears continued and the tears continued to course down her cheeks. Her grey head was full of few and her limbs stiff with cold and damp...... by the time the prayer ended, the grey light of dawn had dimmed the lesser starsonly the morning star shone a pure, silvery white. At last there was peace in her soul. The water was bitter cold and she shuddered as she went down the steps. (Singh p.226-227)

Sabhrai's life is simplicity itself. Hers life is devoted to her family, looking after the needs and comforts of every family member. On many instances; we observe that her world seems to be confined within the lives of her husband and children. Although she does not fully understand the implications of her son's activities, on one occasion when Sher Singh was in the jail and Sabhrai went to meet him, we observe the love, caring of Sabhrai for his son. The novelist vividly describes the heart touching scene as follows:-

Mother and son clasped each other in a tight embrace Sher Sing's pent up emotions burst their bounds and he began to cry loudly in his mother's arms Sabhrai his unmanly tears by holding him to her bosom. She kissed her forehead again and again. (Singh p.231) ${ }^{31}$

Sabhrai further says "How pale you are! Do they give you enough to eat?"

As told by author spiritual persons like Sabhrai are gifted with sixth sense. She could predict that although Beena, her daughter was not alone but she was not protected. So she realized that she could be the victim of Madan's wiles. Her caring for her daughter is clear in the following lines:

Madan's wife had probably had not turned up in Shimla. Even if she had, she was not likely to be able to keep her husband straight............ she dreamt that her daughter was being pursued by a band of hooligans wanting to ravish her and was fanatically calling for help. As the pursuers gained ground, Sabhrai's agitation changed from dream to reality. When they bore upon her child, she yelled at them and opened her arms to protect her daughter. (Singh p.143)

So, she thought of going to Shimla to protect Beena and to her utter surprise, she found Beena to be very sick. The tenderness of her filial love is best expressed in the following lines:

The mother pressed her daughter's head as she chanted. The girl cried, sobbed, sighed and then fell silent.

You have no fever?

.... when did you catch the cold?

'The true, the true.

The Great Guru'. (Singh p.145)

Mrs. Joyce Taylor was so much touched by the plight of a religious mother like Sabhrai that she persuades her husband John Taylor to give a real Christmas gift to Buta Singh's family in the form of release of Sher Singh on the Christmas Day. Joyce Taylor is European counterpart of Sabhrai and she is the embodiment of benevolence and moral goodness.

After his son was released the miserable - Sabhrai recovers her health temporarily and spends some happy moments with the members of her family. Though illiterate Sabhrai did not forget to thank Mrs. Taylor who had persuaded her husband to release her son and writes letter to Mrs.Taylor wherein we her concern for her son is reflected thoroughly.

Dear Taylor Memsahib, I am an uneducated Punjabi woman who cannot write nice words of thanks in English. Ask one of your clerks to read this to you. God bless you for what you have done. You wanted to share the grief of a mother whose child has been stricken. There is no greater act of kindness in the world. (Singh p.254)

But happiness of the family doesn't continue for long because Sabhrai after four days of cheerfulness begins to sink suddenly.

She knows that she is going to die and says "my time has come" (Singh p.258). Her motherly affection for Sher Singh becomes very apparent in the following lines:

Sher Singh was last to arrive. Sabhrai woke up as soon as he came in - just as if she had been waiting for him all the time. She whispered in his ear:'I shall not hear the nightingale, my son. May the Guru give you long life? (Singh p.261) 
She makes the family members recite Granth Sahib. The title of the novel is apt and precise and indicates the importance attached to the character of Sabhrai. In this connection M.K. Naik aptly points out:

The Novel derives its title from her reply to her son's assurance that after Independence, once more the Nightingale will sing. She says, "I shall not hear the Nightingale" -a sentiment in tune with the temper of the novel. (qtd. in Milhoutra p.118)

It seems as if Sabhrai was waiting for her son's release. So, after that she can peacefully go to God's abode. This is a case where love seems to be the cure for pain and grief. Sabhrai and Sher singh's relationship gives a message to the reader that even in the time of crisis it is love which gives the victims strength to face the obstrucles.

A lingering sadness envelops the end of I Shall Not Hear the Nightingale which is not merely the result of the death of the good woman, Sabhrai. With Sabhrai's death, set of values will get eroded and will be replaced by a "brave new world" (with a new connotation of 'brave') in which people like Sabhrai and all that they uphold in the midst of annoying and demoralizing situations, will become either strangers, out of place or extinct. Her death is marked by as much dignity as was her life.

The title of the novel clearly suggests the brooding, solemn vision of the author and can be interpreted in two ways: i) as Sabhrai's lament that she will not be able to witness the Independence of the country, and ii) as the death of beauty and goodness of the nightingale-symbolized by Sabhrai. Nightingale stands for happiness and also independence. Sabhrai knows that India will soon get independence but she knows that she will not there to enjoy the freedom.

The deceptively structured surface of the book contains underneath a heart rendering message. Commenting on the ending of the novel the author writes "All's well that ends well."

This holds the key to the basic question of the novelist's evaluation of experience as presented in I Shall Not Hear the Nightingale. This experience is multifaceted and multidimensional and comprises social, political, moral and religious strands. (Dhawan P.108) ) $^{38}$

Khushwant Singh's treatment of sex in I Shall Not Hear the Nightingale is more artistic than what we find in his novel The Company of Women. In The Company of Women almost all women are seen sexually hungry where as in I Shall Not Hear the Nightingale, Sabhrai is an elderly and a spiritualist, Madan's sister is unconcerned with sex while Beena, Sher Singh's sister is once entrapped and is passionately hungry for sex, but later on she retreats finding her sister in law Champak with Madan.

Khushwant Singh has presented the ideal and the real world in Juxtaposition in the novel. On the one hand through the characters like Sabhrai and Mrs.Taylor, he tries to explore the ideal world as discussed and advised by Indian philosophical schools and on the other hand he unfolds the real world of oddities and menace through the characters like Champak or Madan.

\section{References}

[1] Singh, P.K.The Novels of Khushwant Singh A Critical Evaluation,Jaipur:Book Enclave,2005

[2] Singh, Khushwant.I Shall Not Hear the Nightingale, New Delhi: Ravi Dayal Publisher, 1997

[3] Kumar, Ranjan.Khushwant Singh As a Novelists, New Delhi:R.D.Pandey Satyam Publishing Home,2010

[4] Dubey,S.K.Khushwant Singh: A Critical Study of His Novels,Delhi:B.R.Publication Corportion,1999

[5] Milhoutra, Dr.Ruby.Studies in Indian English Fiction and poetry (ed.), New Delhi:Sarup and Sons:2003

[6] Dhawan, R.K. Three Contemporary Novelists. New Delhi: Classical Publishing Company, 1985. p. 36. 